\title{
Ethnologies
}

\section{Dance in Canada}

Contemporary Perspectives

\section{Danse au Canada}

\section{Perspectives contemporaines}

\section{Marcia Ostashewsky, Sherry Johnson et Kristin Harris Walsh}

Volume 30, numéro 1, 2008

Danse au Canada

Dance in Canada

URI : https://id.erudit.org/iderudit/018832ar

DOI : https://doi.org/10.7202/018832ar

Aller au sommaire du numéro

Éditeur(s)

Association Canadienne d'Ethnologie et de Folklore

ISSN

1481-5974 (imprimé)

1708-0401 (numérique)

Découvrir la revue

Citer ce document

Ostashewsky, M., Johnson, S. \& Walsh, K. H. (2008). Dance in Canada:

Contemporary Perspectives. Ethnologies, 30(1), 5-20.

https://doi.org/10.7202/018832ar d'utilisation que vous pouvez consulter en ligne.

https://apropos.erudit.org/fr/usagers/politique-dutilisation/ 


\section{DANCE IN CANADA}

Contemporary Perspectives

$\begin{array}{lcc}\text { Marcia Ostashewsky } & \text { Sherry Johnson } & \text { Kristin Harris Walsh } \\ \text { Nipissing University } & \text { York University } & \text { Memorial University }\end{array}$

Dance ethnographies bring dance studies together with folklore and thus provide significant subject matter for this special issue of Ethnologies. Historical and genre-based approaches to dance have long been the norm in dance studies; however, by the 1960s, research conducted by self-identified "dance anthropologists" began to explore wider social processes and cultural contexts of dance performances and productions. Earlier studies, such as Joann Kealiinohomoku's article "An Anthropologist Looks at Ballet as a Form of Ethnic Dance" (1969), and later works like Judith Lynne Hanna's Dance, Sex and Gender (1988), used anthropological perspectives to study dance forms previously not considered in this way. These American scholars paved the way for an acceptance of ethnography, among dance researchers, as an appropriate methodology for thinking about and writing about dance. Moreover, the inclusion of the ideas of scholars such as Kealiinohomoku (in Dorson's 1972 Folklore and Folklife: An Introduction) and Adrienne Kaeppler (in Richard Bauman's 1992 Folklore, Cultural Performances and Popular Entertainments) in folklore anthologies illustrates the beginnings of dance/folklore links through ethnographic approaches. These anthropologically inspired dance writings encouraged scholars to reflect on the importance of dance communities, their performers and audience members, and the social and cultural contexts in which dancing occurs. Both dance studies and folklore studies have influenced the work of all the authors whose articles appear in this issue. 
Not only did these early dance ethnographies emphasize the significance of context and function of dance forms with regard to understandings of the significance of dance as a part of culture, they also helped to break down the distinctions between so-called "high art" and "low art"; folk, national, and ethnic dance became "vernacular dance." This in turn resulted in a shift in perceptions of vernacular dance. Susan Eike Spalding and Jane Harris Woodside, for instance, define it in the introduction to their collection of articles, Communities in Motion: Dance, Community and Tradition in America's Southeast and Beyond: vernacular dance is "dance that is community based and is shaped and perpetuated by the traditional process; it can either be social or performance oriented in character" (1995: 2). Earlier considered as something raw, unskilled and aesthetically unrefined, vernacular dance is now understood in relation to specific groups of people, accessible, localized, and popular.

The articles published in this issue were submitted in response to a call for articles exploring concepts of tradition, reinvention, revival, heritage and identity as enacted in and by diverse dancers and dance communities. We encouraged analyses that addressed dance of any contemporary or historical genre and/or performance context, drawn on expansive notions of ethnological inquiry through dance as narrative symbolic practice, as narrative construction, as cultural agency in performance, and practiced through regional, national, and transnational contexts. In essence, we wanted to elicit new scholarship on the shifting nature of "the traditional" in dance as understood in social and cultural contexts through ethnographic practices.

The following articles are written by scholars living and working in different parts of our country; together, they address a variety of dance genres. The interdisciplinary work of the authors published in this issue, scholars who have studied in and come from fields such as folklore and ethnology, anthropology, ethnomusicology and cultural studies, have encouraged a wide and rich outlook on dance in Canada. The method of the diverse research gathered here, ethnography, is something that all the articles share. The authors' use of ethnography is not limited by perspectives grounded in one or the other discipline, but has encouraged them to find compelling ways of giving voice to the importance of dance in the lives of individuals and communities about whom they write. Further, the three guest editors of this issue are young scholars who are trained in, and who publish and teach in, a variety of 
interdisciplinary arts and culture programs; their work also shares a common ethnographic impetus. The insights that emerge amidst and between all the writings in this issue have, no doubt, been enabled by and through the variety of interdisciplinary approaches taken by the authors.

The articles in this issue are arranged in order to first introduce the reader to some of the dance research that has been conducted in Canada, then engage the reader with materials that relate to wide-ranging dance practices in Canada, and finally focus the reader's attention on the dance production of small groups and individuals. This arrangement of articles takes the reader from the most generalized studies - of research - to the most specific — of highly personalized dance practices. This seemingly straightforward structure is problematized, though, by the fact that the individual articles interconnect with one another in more complicated ways. More specifically, the corpus of articles as a whole identifies several core theoretical issues; yet not all of the articles raise the same complex of questions. The body of material presented in this issue, altogether, demonstrates how specific and localized examples of dance connect with larger social processes. Other, more defined theoretical issues raised in the individual articles interlock and overlap within and between the articles. The structure of the issue thus invokes the very nature of dance communities and practices in the lives of so many of us who find and make dance meaningful in our lives, since dance is interwoven through many dimensions of our own experiences and memories as dancers and scholars.

While there already exists a small number of very fine dance studies publications in Canada, upon which this issue builds, this one may be unique in that it brings together research that is grounded in the contemporary ethnography of dance. It speaks to both the burgeoning international interest over the past several decades in ethnographic and ethnological studies of dance, as well as the growing interest among dance scholars in Canada to engage in ethnographic approaches to dance. The opening article in this issue describes pioneering dance scholar Gertrude Kurath's contributions to dance ethnography, focusing particularly on her work amongst First Nations in Canada. Author Mary Caldwell argues that Kurath "foreshadow[ed] the redefinitions of fieldwork in the twentieth and twenty-first centuries", and raises a number of issues in ethnographic methodology — including those of fieldwork practices, participant observation, relationships with 
participants and the use of dance notation - that are also taken up by other authors as they discuss their own work. This attention to ethnographic processes in all stages of the research endeavor is an underlying theme of this issue.

Almost all of the articles examine how traditional or vernacular practices are transformed through time and space. Sarah Quick uses Michael Herzfeld's concept of social poetics as a lens through which to view how performances of the Red River Jig emerge through social interaction. She describes how the youngest generations of Métis are currently using the Red River Jig to express their understanding of their place in the world. Likewise, Nicola Mooney explores how hybrid performances of bhangra complicate the role of this dance in the maintenance of Jat Sikh identity in Canadian contexts. Both Quick and Mooney emphasize how both older and newer manifestations of their respective dance traditions are significant for - and used strategically by - different members of their communities. Similarly, Kristin Harris Walsh explores how contextual shifts from the social to the performative, through processes of modernization, cultural revival, and globalization, have enabled the vernacular tradition of IrishNewfoundland step dancing to survive and flourish. Andriy Nahachewsky and Jillian Staniec consider the ways in which individuals and communities of interest can shape traditions, based on particular choices that are made in relation to production and performance practices. While Bridget Cauthery discusses contemporary dance, she focuses on the vernacular belief practice of trance or transformation as a key element in the creation of Margie Gillis's dance pieces.

The role of dance in the construction, maintenance, and contestation of identity is another theme running through many of the articles in this issue. Dance is used to both complicate and reify essentialist representations of culture and identity that circulate in mainstream society. For example, Quick describes how performances of the Red River Jig "emerge as indexes to social interactions and points of view not necessarily in line with a fixed national narrative of Métis identity." In contrast, Mooney explains how Jat Sikhs perform roots bhangra as a way of constructing a bounded identity to differentiate themselves from non-Jats; hybrid forms of bhangra are understood to challenge or diminish notions of identity. Staniec writes about how different political values are implicated in the choices individuals and groups of Canada's Ukrainians have made in relation to the ways in which they align 
themselves with dance companies, practices and styles. Conversely, Nahachewsky's article addresses the roles of individuals and dance groups in the construction and maintenance of folk dance revivals. Harris Walsh understands the St. Pat's Dancers group to be an embodiment of Irish identity in Newfoundland. Despite the fact that people of Irish descent have never constituted an ethnic majority in the province, Newfoundlanders tend to identify with Irish culture through a variety of cultural products, including vernacular dance. Harris Walsh suggests that this is because Newfoundland and Ireland share perceived and real similarities that have encouraged Newfoundland to model itself after Ireland, perhaps in part because cultural products are often most strongly preserved in communities distant from the geographical homeland.

It is no surprise that, at the beginning of the twenty-first century, transnationalism emerges as a significant factor in the development of dance practices. Harris Walsh discusses the impact of the global Riverdance phenomenon on Irish-Newfoundland step dancing, while Mooney explores how recent Jat Sikh immigrants to Canada use traditional bhangra and giddha performance as a means of constructing their identity in relation to their rural homeland. Staniec describes the circulation of political values along with dance practices, which travel with individuals and groups of people between homeland and diaspora communities, and also between different diaspora communities. The folk dance revivals that Nahachewsky writes about are often the product of immigrant communities, which are themselves the result of the transnational movement of people; revival practices are also characterized according to specific histories of transmission, of practices and related ideas, between various revival communities.

The importance of embodied knowledge arises in several of the articles. For example, Katherine Cornell's reflections on her reactions to Marie Chouinard's piece Des feux dans la nuit focus on the transference of the chora from dancer to audience member through the stillness and flurry inherent in this dance piece. Cornell's analysis illustrates the power of the body, not just in the performing dancer, but in the watching spectator as well. Cauthery's article focuses on dancer Margie Gillis' embodiment of trance in her choreography as a way of both connecting to the audience and providing a visual representation of her philosophical approach to life. Quick describes how she learned the Red River Jig, flagging the importance of this kind of kinesthetic 
knowledge to her overall understanding of the meaning of the Red River Jig. Mooney asks dancers to describe how performing different manifestations of bhangra affects how they understand themselves and their relationship to their Punjab homeland, as well as their new life in Canada.

The relationship between music and dance is important, though, surprisingly, it has tended to be overlooked in much dance scholarship; music as an intrinsic element of dance is discussed in several pieces in this issue. Ethnomusicologist Quick provides a detailed description of the Red River Jig, including both footwork and choreography, in relation to the particular tune(s) most often used for its performance. Mooney also explains the relationship between the music and dance, and particularly how changes in one influence the other. Cornell's approach examines not the relationship between dance and music, but the connection between dance and the writing spectator. Her autoethnographic descriptions of her kinesthetic responses to Chouinard's work are reminiscent of musicality through her eyes as an audience member.

Finally, the collection of articles in this issue provides insight into many issues for future work in dance studies in Canada. We hope that this journal issue will initiate more work from scholars addressing the gap in dance and folklore studies relating to the application of ethnographic and anthropological approaches to dance in Canada. As editors, we have been required to make choices with regard to articles that provide accompaniment to one another in this issue, primarily in relation to the conflation of the vast geographic, ethnic and historical lineages that exist in a country as large and diverse as Canada. This issue addresses a broad spectrum of historical and contemporary dance, engaging with a number of communities, regions and ethnic groups within the complex milieu of what it is to be a dancer in Canada. As ethnicity, region and community may be markers of hegemony, resistance, political power and protest, so may dance be considered the embodiment of such concepts. It is primarily through ethnography that the social and cultural issues illuminated by dance may be unearthed and understood. Ethnographic dance research in Canada is beginning to engage with salient issues of identity and community. We hope that this issue encourages, for the many excellent scholars whose work addresses these topics, our continued and mutually supportive work in this regard. 


\section{References}

Hanna, Judith Lynne. 1988. Dance, Sex and Gender: Signs of Identity, Dominance, Defiance and Desire. Chicago: University of Chicago Press.

Kaeppler, Adrienne L. 1992. "Dance." In Richard Bauman, ed., Folklore, Cultural Performances and Popular Entertainments: 196-203. Oxford: Oxford University Press.

Kealiinohomoku, Joann Wheeler. 1969. "An Anthropologist Looks at Ballet as a Form of Ethnic Dance." Journal for the Anthropological Study of Human Movement 1 (2): 83-97.

_. 1972. "Folk Dance". In Richard M. Dorson, ed., Folklore and Folklife: An Introduction: 381-404. Chicago: University of Chicago Press.

Spalding, Susan Eike and Jane Harris Woodside, eds. 1995. Communities in Motion: Dance, Community and Tradition in America's Southeast and Beyond. Westport CT: Greenwood Press. 



\section{Danse Au CANADA}

Perspectives contemporaines

Marcia Ostashewsky

Nipissing University
Sherry Johnson

York University
Kristin Harris Walsh

Memorial University

Les diverses études ethnographiques portant sur la danse ont fait entrer les recherches sur la danse dans le champ de l'ethnographie et procurent donc un sujet significatif à ce numéro spécial d'Ethnologies. Longtemps, la norme pour les études du domaine de la danse était celle d'une approche historique ou basée sur le genre ; cependant, au cours des années 1960, les recherches menées par ceux qui se définissaient eux-mêmes comme des "anthropologues de la danse » ont commencé à explorer des processus sociaux et des contextes culturels plus larges des performances et des productions de la danse. Les premières études, comme celle de Joann Kealiinohomoku dans son article "An Anthropologist Looks at Ballet as a Form of Ethnic Dance» (1969) et des travaux ultérieurs, tels que celui de Judith Lynne Hanna, Dance, Sex and Gender (1988), ont employé des perspectives anthropologiques pour étudier des formes de danse que l'on n'envisageait pas de cette manière auparavant. Ces chercheures américaines ont défriché le terrain pour que les chercheurs de ce domaine puissant envisager que l'ethnographie constitue une méthodologie appropriée pour penser et écrire à propos de la danse. De plus, l'incorporation d'idées d'universitaires telles que Joann Wheeler Kealiinohomoku (1972, dans Folklore and Folklife. An Introduction) et Adrienne Kaeppler (1992, dans Folklore, Cultural Performances and Popular Entertainments) dans des anthologies de folklore marque le début des liens entre danse et folklore à travers des approches ethnographiques. Ces écrits sur la danse, inspirés 
par l'anthropologie, ont incité les chercheurs à réfléchir à l'importance des communautés dans le domaine de la danse, à leurs praticiens et à leurs publics, et aux contextes sociaux et culturels dans lesquels on danse. Tant les études sur la danse proprement dite que l'ethnologie ont influencé les travaux des auteurs dont les articles apparaissent dans ce numéro.

Ces premières ethnographies sur la danse n'ont pas seulement souligné l'importance du contexte et de la fonction des formes de danse sous l'angle d'une compréhension de la signification de la danse en tant qu'élément de la culture ; elles ont également contribué à affaiblir les distinctions entre ce que l'on appelait le «grand art» et les «arts mineurs » : les danses folkloriques, nationales et ethniques sont devenues des «danses vernaculaires ». En retour, cela permit de faire évoluer les perceptions de la danse vernaculaire. Susan Eike Spalding et Jane Harris Woodside, par exemple, l'ont définie dans l'introduction de leur recueil d'articles, Communities in Motion. Dance, Community and Tradition in America's Southeast and Beyond: la danse vernaculaire est une "danse qui prend sa source dans une communauté et qui est mise en forme et perpétuée par le processus traditionnel; elle peut être par nature soit sociale, soit tournée vers la performance » (1995: 2, traduction libre). Auparavant considérée comme quelque chose de brut, ne demandant pas d'aptitudes particulières et dépourvue d'intention esthétique, la danse vernaculaire est aujourd'hui comprise sur le mode de sa relation à des groupes de gens spécifiques; elle est accessible, localisée et populaire.

Les articles présentés dans ce numéro ont été soumis en réponse à un appel à communications et ils devaient explorer les concepts de tradition, de réinvention, de revival, de patrimoine et d'identité tels qu'ils se jouent dans diverses communautés de danse et sous l'impulsion de différents danseurs. Nous avons sollicité des analyses portant sur la danse historique ou contemporaine, peu importe le contexte de performance ou de genre, qui se baseraient sur les notions d'enquêtes ethnographiques au sens large, et qui concevraient la danse comme pratique narrative symbolique, construction narrative, moyen d'agir culturel par l'intermédiaire de la performance, ces danses étant pratiquées dans des contextes régionaux, nationaux et transnationaux. Nous souhaitions essentiellement attirer l'attention de nouveaux chercheurs sur la nature mouvante du «traditionnel » dans le domaine de la danse, 
tel qu'on le comprend dans les contextes sociaux et culturels à travers les pratiques ethnographiques.

Les articles qui suivent ont été rédigés par des universitaires vivant et travaillant dans différentes régions de notre pays; ensemble, ils se penchent sur une grande variété de types de danses. Le travail interdisciplinaire des auteurs publiés dans ce numéro, chercheurs provenant de champs d'études aussi divers que le folklore et l'ethnologie, l'anthropologie, l'ethnomusicologie et les études culturelles, permet d'envisager de manière étendue et fructueuse la danse au Canada. La méthode des différentes recherches rassemblées ici, l'ethnographie, est le point commun de tous ces articles. L'usage que font ces auteurs de l'ethnographie ne se limite pas aux perspectives d'une discipline en particulier, mais les a plutôt incités à rechercher une manière frappante d'attirer l'attention sur l'importance de la danse pour les individus et les communautés qu'ils décrivent, et de leur donner voix au chapitre. En outre, les trois rédactrices invitées de ce numéro sont de jeunes universitaires qui ont été formées, qui publient et qui enseignent dans divers programmes interdisciplinaires d'art et de culture ; elles ont également en partage, dans leur travail, le même intérêt pour l'ethnographie. Les apercus et les idées qui se dévoilent à travers tous les écrits de ce numéro sont, sans aucun doute, nés des approches interdisciplinaires diversifiées de leurs auteurs.

Les articles de ce numéro thématique sont ordonnés de manière à présenter tout d'abord au lecteur quelques-unes des recherches sur la danse menées au Canada, ensuite à l'amener à la rencontre des matériaux relatifs aux pratiques très étendues de la danse au Canada, puis à attirer son attention sur les productions de petits groupes et d'individus. L'ordonnancement des articles fait passer le lecteur des études d'ordre plus général — de la recherche — à celles de nature plus spécifique - des pratiques de danse hautement personnalisées. Cette structure apparemment directe est problématisée, cependant, par le fait que les articles individuels entrent en interconnexion de manière plus complexe. Plus spécifiquement, l'ensemble de ces articles permet d'identifier plusieurs problèmes théoriques centraux; mais cependant, ils ne soulèvent pas tous les mêmes ensembles de questions. Les matériaux présentés dans ce numéro, considérés dans leur ensemble, démontrent à quel point les exemples de danses spécifiques et localisées sont connectées aux processus sociaux plus larges. D’autres questions théoriques, plus poussées, soulevées dans les articles individuels, 
s'emboîtent avec celles d'autres articles ou les recoupent. La structure de ce numéro évoque donc la nature elle-même des communautés de danse et de leurs pratiques dans les vies de nombre d'entre nous pour qui la danse donne un sens à nos vies, la danse étant entremêlée à de nombreuses dimensions de nos propres expériences et de nos mémoires en tant que danseuses et qu'universitaires.

Bien qu'il existe déjà un petit nombre d'excellentes publications sur la danse au Canada, sur lesquelles se base ce numéro, ce dernier est unique en ce qu'il rassemble des recherches qui se fondent sur l'ethnographie contemporaine de la danse. Il interpelle à la fois l'intérêt qui est né au cours des dernières décennies, au niveau international, pour les études ethnographiques et ethnologiques de la danse, autant que l'intérêt naissant des chercheurs du domaine de la danse au Canada pour les approches ethnographiques de la danse. L'article d'ouverture de ce numéro décrit les travaux de la chercheure Gertrude Kurath, pionnière des recherches sur la danse, et sa contribution à l'ethnographie de la danse, en particulier dans le cadre de ses travaux auprès des Premières nations du Canada. Son auteure, Mary Caldwell, avance que les travaux de Kurath " annonçaient les redéfinitions du travail de terrain au $\mathrm{XX}^{\mathrm{e}}$ et au XXI $\mathrm{X}^{\mathrm{e}}$ siècles », et soulève un certain nombre de questions relatives à la méthodologie ethnographique - y compris celles des pratiques de terrain, de l'observation participante, des relations avec les participants et de l'usage de la transcription des figures de danse qui sont également reprises par d'autres auteurs lorsqu'ils exposent leur propre travail. Cette attention portée aux processus ethnographiques à tous les stades de l'entreprise de recherche court en filigrane dans tout ce numéro.

Presque tous les articles examinent comment les pratiques traditionnelles ou vernaculaires se transforment à travers le temps et les lieux. Sarah Quick utilise le concept de la poétique sociale de Michael Herzfeld comme une loupe qui lui permet d'observer comment les performances de la gigue de la Rivière rouge émergent des interactions sociales. Elle décrit comment les plus jeunes générations de Métis utilisent aujourd'hui la gigue de la Rivière rouge pour exprimer la manière dont ils conçoivent leur place en ce monde. De manière semblable, Nicola Mooney explore par quel biais les performances hybrides du bhangra compliquent le rôle de cette danse dans la conservation d'une identité des Sikhs Jat en contexte canadien. Tant Quick que Mooney soulignent que les manifestations les plus anciennes 
comme les plus nouvelles de la tradition de danse qu'elles étudient respectivement sont signifiantes pour — et utilisées de manières stratégiques par - différents membres de la communauté. De manière similaire, Kristin Harris Walsh explore comment les déplacements contextuels, du social au performatif, à travers les processus de modernisation, de revival culturel et de mondialisation ont permis à la tradition vernaculaire de la step dance des Irlandais de Terre-Neuve de survivre et de prospérer. Andriy Nahachewsky et Jillian Staniec considèrent les manières par lesquelles les individus et les communautés d'intérêts peuvent redonner forme aux traditions, en se basant sur des choix particuliers faits en fonction des pratiques de production et de performance. Et, tandis que Bridget Cauthery discute de la danse contemporaine, elle se penche plus particulièrement sur la croyance vernaculaire de la pratique de la transe ou de la transformation comme élément clé des créations choréographiques de Margie Gillis.

Le rôle de la danse dans la construction, l'entretien et la contestation de l'identité constitue un autre de ces thèmes qui courent à travers plusieurs des articles de ce numéro. La danse sert aussi à compliquer et à réifier les représentations essentialistes de la culture et de l'identité qui circulent dans le courant de pensée dominant de la société. Par exemple, Quick décrit comment les performances de la gigue de la Rivière rouge «se laissent voir comme un index d'interactions sociales et de points de vue qui ne concordent pas nécessairement avec un récit national figé de l'identité métis ». Par contraste, Mooney explique que les Sikhs Jat exécutent le bhangra le plus proche de leurs racines comme une manière de tracer des frontières autour de leur identité pour se différencier des non-Jats; les formes hybrides du bhangra sont perçues comme des défis ou des atteintes à la notion d'identité. Staniec se penche sur les différentes valeurs politiques impliquées dans les choix qu'ont fait les individus et les groupes d'Ukrainiens canadiens en ce qui concerne les manières par lesquelles ils s'affilient aux pratiques et aux styles des compagnies de danse. À l'inverse, l'article de Nahachewsky porte sur les rôles des individus et des groupes de danse dans la construction et la pérennisation des revivals de danse folklorique. Harris Walsh envisage le groupe des danseurs de St. Pat comme une incarnation de l'identité irlandaise à Terre-Neuve. En dépit du fait que les gens d'ascendance irlandaise n'ont jamais constitué une majorité ethnique dans la province, les habitants de Terre-Neuve ont tendance à s'identifier à la culture irlandaise par le biais d'une variété de produits culturels, y compris la 
danse vernaculaire. Harris Walsh suggère qu'il en est ainsi parce que Terre-Neuve et l'Irlande partagent certaines similitudes, perçues ou réelles, qui ont incité les habitants de Terre-Neuve à prendre modèle sur l'Irlande, peut-être en partie parce que les produits culturels sont souvent mieux et plus fortement conservés dans des communautés distantes géographiquement de leur pays d'origine.

Il n'est guère étonnant que, au début du XXI ${ }^{\text {e }}$ siècle, le transnationalisme soit devenu un facteur d'importance dans le développement des pratiques de danse. Harris Walsh discute de l'impact du phénomène mondial de la Riverdance sur la step dance irlandoterre-neuvienne, tandis que Mooney explore la manière dont les nouveaux immigrants Sikhs Jat utilisent les performances traditionnelles du bhangra et du giddha comme un moyen de construire leur identité en relation avec leur patrie rurale. Staniec décrit la circulation des valeurs politiques qui vont de pair avec les pratiques de danse, qui voyagent avec les individus et les groupes de gens entre le pays d'origine et les communautés de la diaspora, ainsi qu'entre différentes communautés de la diaspora. Les revivals de danse folklorique examines par Nahachewsky sont souvent produits par des communautés d'immigrants qui sont elles-mêmes le produit d'un movement transnational de personnes; les pratiques de ce renouveau prennent forme également en fonction d'histoires spécifiques de transmission, de pratiques et d'idées associées, entre les différentes communautés de ces revivals.

L'importance de l'incorporation de la connaissance se laisse entrevoir dans plusieurs de ces articles. Par exemple, les réflexions de Katherine Cornell au sujet de ce qu'elle avait ressenti devant la chorégraphie de Marie Chouinard, Des feux dans la nuit, se concentrent sur le transfert de la chora, de la danseuse aux spectateurs, à travers la tranquillité et l'agitation soudaine particulières à cette oeuvre. L'analyse de Cornell souligne le pouvoir du corps, non seulement chez la danseuse en action, mais sur le spectateur qui la regarde tout autant. L'article de Cauthery se penche sur l'incarnation de la transe par la danseuse Margie Gillis dans le cadre de ses chorégraphies comme une manière à la fois de se connecter au public et de donner une représentation visuelle de son approche philosophique de la vie. Quick décrit la manière dont elle a appris la gigue de la Rivière rouge, mettant de l'avant l'importance pour elle de ce type de connaissance kinesthésique pour sa compréhension d'ensemble de la signification de la gigue de la Rivière 
rouge. De son côté, Mooney a demandé aux danseurs de décrire en quoi les différentes performances du bhangra affectent leur compréhension d'eux-mêmes et de leur relation avec leur patrie, le Pendjab, autant que leur nouvelle vie au Canada.

Le rapport entre musique et danse est important bien que, et le fait est étonnant, beaucoup d'études sur la danse aient eu tendance à l'éluder; la musique en tant qu'élément intrinsèque de la danse est évoquée dans plusieurs articles de ce numéro. Quick, d'un point de vue d'ethnomusicologue, nous offre une description détaillée de la gigue de la Rivière rouge, y compris les pas et la chorégraphie, en relation avec les airs particuliers utilisés le plus souvent pour cette performance. Mooney explique également la relation entre musique et danse, en particulier la manière dont les changements de l'une influencent l'autre. Cornell utilise pour approche, non la relation entre la danse et la musique, mais la connexion entre la danse et le spectateur qui écrit. Ses descriptions autoethnographiques de ses réponses kinesthésiques à l'oeuvre de Chouinard offrent des réminiscences de musicalité à travers ses yeux de spectatrice.

Enfin, ce recueil d'articles fournit des aperçus sur beaucoup de questions qui feront l'objet de travaux ultérieurs dans les études de danse au Canada. Nous espérons que ce numéro thématique inspirera d'autres travaux à des chercheurs préoccupés par le clivage entre les études de danse et d'ethnologie sur le plan de la mise en oeuvre d'approches ethnographiques et anthropologiques de la danse au Canada. En tant que rédactrices invitées, nous avons dû procéder à certains choix, afin que les différents articles s'accompagnent les uns les autres dans ce numéro spécial, surtout sur le plan de la convergence des longues lignées géographiques, ethniques et historiques que l'on trouve dans un pays aussi grand et diversifié que le Canada. Ce numéro thématique expose un large spectre de danses historiques et contemporaines, se penche sur un certain nombre de communautés, de regions et de groupes ethniques dans le cadre du milieu complexe de ce que signifie être un danseur au Canada. Si l'ethnicité, la région et la communauté peuvent être les marqueurs de l'hégémonie, de la résistance, du pouvoir politique et de la contestation, alors la danse peut être considérée comme l'incarnation de tels concepts. C'est en premier lieu par l'intermédiaire de l'ethnographie que les questions sociales et culturelles que la danse met en lumière peuvent être mises au jour et comprises. La recherche ethnographique sur la danse au 
Canada commence à s'intéresser aux questions essentielles d'identité et de communauté. Nous espérons que ce numéro spécial, destiné à ces nombreux chercheurs très qualifiés dont les travaux se penchent sur ces sujets, contribuera de ce point de vue à encourager nos travaux continus, dans un esprit d'entraide mutuelle.

\section{Références}

Hanna, Judith Lynne, 1988, Dance, Sex and Gender. Signs of Identity, Dominance, Defiance and Desire. Chicago: University of Chicago Press.

Kaeppler, Adrienne L., 1992, «Dance». Dans Richard Bauman (dir.), Folklore, Cultural Performances and Popular Entertainments. Oxford, Oxford University Press : 196-203.

Kealiinohomoku, Joann Wheeler, 1969, «An Anthropologist Looks at Ballet as a Form of Ethnic Dance ». Journal for the Anthropological Study of Human Movement 1 (2) : 83-97.

_. 1972, «Folk Dance». Dans Richard M. Dorson (dir.), Folklore and Folklife. An Introduction. Chicago, University of Chicago Press : 381-404.

Spalding, Susan Eike et Jane Harris Woodside (dir.), 1995, Communities in Motion. Dance, Community and Tradition in America's Southeast and Beyond. Westport CT: Greenwood Press. 